\title{
Introducing a new volume of Neurodegenerative Disease Management
}

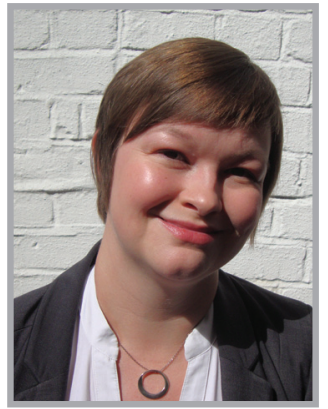

"The beginning of a new year is always a good time to look back, and it is interesting to reflect on the articles published by the journal in 2016, especially those that were most popular with our readers."

\section{Laura Dormer*}

Welcome to volume 7 of Neurodegenerative Disease Management. In this first issue of the year, we feature a broad range of topics and article types, which we hope our readers will find both useful and interesting.

\section{In the issue}

In this issue, review content includes an update on the use of teriflunomide, the once-daily, oral disease-modifying therapy for the treatment of multiple sclerosis (MS), from Dr Aaron E Miller [1]. Also included is a look at the use of menopause hormone therapy in women, and the impact this could potentially have on the prevention of Alzheimer's disease, cerebrovascular disease and aging-related cognitive impairment and dementia, from Davey et al. [2] .

Original research is presented in the areas of MS and Parkinson's disease. In the first paper [3], Klaren et al. examine the link between brain volume and sedentary behavior in persons with MS. In a further paper, Hendin et al. conduct a Delphi analysis of the ALLOW study to obtain consensus on injection-site reaction experience and mitigation strategies for patients with relapsing-remitting MS switching from non-pegylated interferons to peg-IFN- $\beta$-1a [4].

Three further papers are included in the area of Parkinson's disease research. Two papers from Zesiewicz et al. examine the use of ropinirole prolonged release, a nonergoline dopamine agonist, in early-stage [5] and advanced Parkinson's disease [6]. A further paper from Khalil et al. discusses a pilot study evaluating the feasibility of home-based exercise for Parkinson's patients in Jordan [7].

The issue also includes an interview with Dr Ralph Kern from Biogen (MA, USA), discussing the research presented at the autumn Congress of the European Committee for Treatment and Research in Multiple Sclerosis [8].

\section{Highlights from 2016}

The beginning of a new year is always a good time to look back, and it is interesting to reflect on the articles published by the journal in 2016, especially those that were most popular with our readers.

Table 1 shows the top 20 most read articles from our 2016 issues (as of 25 November 2016), and as expected, articles

*Commissioning Editor, Neurodegenerative Disease Management, Future Medicine Ltd, Unitec House, London, N3 1QB, UK; I.dormer@futuremedicine.com

\section{“Awareness of our journal continues to grow, and this year saw the important milestone of the journal being accepted for coverage on Web of Science...”}

\section{KEYWORDS}

- Biogen • community engagement

- MS • Parkinson's disease • readership

- Web of Science

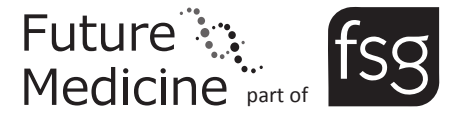


Table 1. Top 20 Neurodegenerative Disease Management 2016 articles by readership .

\begin{tabular}{|c|c|c|c|c|c|}
\hline Rank & Article title & Authors & Article type & Access status & Ref. \\
\hline 1 & $\begin{array}{l}\text { Gavin Giovannoni on why time matters in multiple } \\
\text { sclerosis }\end{array}$ & Giovannoni G & Interview & Free access & [9] \\
\hline 2 & A $\beta$ immunotherapy for Alzheimer's disease: where are we? & $\begin{array}{l}\text { Güell-Bosch J, Montoliu-Gaya L, } \\
\text { Esquerda-Canals G, Villegas S }\end{array}$ & Editorial & Free access & [10] \\
\hline 3 & $\begin{array}{l}\text { Clinical studies of GBA1-associated parkinsonism: progress } \\
\text { and challenges }\end{array}$ & $\begin{array}{l}\text { Lopez G, Monestime G, } \\
\text { Sidransky E }\end{array}$ & Editorial & Free access & [11] \\
\hline 4 & Dementia and caregiver stress & $\begin{array}{l}\text { Zwerling JL, Cohen JA, } \\
\text { Verghese J }\end{array}$ & Editorial & Free access & [12] \\
\hline 5 & B-cell-directed therapies in multiple sclerosis & Gasperi C, Stüve O, Hemmer B & Drug Evaluation & $\begin{array}{l}\text { Subscriber } \\
\text { content }\end{array}$ & [13] \\
\hline 6 & $\begin{array}{l}\text { Alzheimer's disease: the potential therapeutic role of the } \\
\text { natural antibiotic amyloid- } \beta \text { peptide }\end{array}$ & $\begin{array}{l}\text { Kumar DKV, Eimer WA, Tanzi RE, } \\
\text { Moir RD }\end{array}$ & Editorial & Free access & [14] \\
\hline 7 & Emerging therapies in Friedreich's ataxia & $\begin{array}{l}\text { Aranca TV, Jones TM, Shaw } \\
\text { JD et al. }\end{array}$ & Review & $\begin{array}{l}\text { Subscriber } \\
\text { content }\end{array}$ & [15] \\
\hline 8 & $\begin{array}{l}\text { Clinical management of patients with advanced } \\
\text { Parkinson's disease treated with continuous intestinal } \\
\text { infusion of levodopa/carbidopa }\end{array}$ & $\begin{array}{l}\text { García DS, Castrillo JCM, Périz } \\
\text { VP et al. }\end{array}$ & Drug Evaluation & Free access & [16] \\
\hline 9 & $\begin{array}{l}\text { Can microbiota research change our understanding of } \\
\text { neurodegenerative diseases? }\end{array}$ & Scheperjans F & Commentary & $\begin{array}{l}\text { Subscriber } \\
\text { content }\end{array}$ & [17] \\
\hline 10 & $\begin{array}{l}\text { Multiple sclerosis in the very young: a case report and } \\
\text { review of the literature }\end{array}$ & Sivaraman I, Moodley M & Case Study & $\begin{array}{l}\text { Subscriber } \\
\text { content }\end{array}$ & [18] \\
\hline 11 & $\begin{array}{l}\text { Freezing of gait in Parkinson's disease: from } \\
\text { pathophysiology to emerging therapies }\end{array}$ & $\begin{array}{l}\text { Cucca A, Biagioni MC, Fleisher } \\
\text { JE et al. }\end{array}$ & Review & $\begin{array}{l}\text { Subscriber } \\
\text { content }\end{array}$ & [19] \\
\hline 12 & $\begin{array}{l}\text { Traumatic brain injury as a risk factor for Alzheimer's } \\
\text { disease: current knowledge and future directions }\end{array}$ & $\begin{array}{l}\text { Dams-O'Connor K, Guetta G, } \\
\text { Hahn-Ketter AE, Fedor A }\end{array}$ & Perspective & $\begin{array}{l}\text { Subscriber } \\
\text { content }\end{array}$ & [20] \\
\hline 13 & $\begin{array}{l}\text { Design of evidence-based gardens and garden therapy for } \\
\text { neurodisability in Scandinavia: data from } 14 \text { sites }\end{array}$ & Spring JA & $\begin{array}{l}\text { Short } \\
\text { Communication }\end{array}$ & Open access & [21] \\
\hline 14 & $\begin{array}{l}\text { Elucidating the link between the modifiable risk factors of } \\
\text { Alzheimer's disease and neuroinflammation }\end{array}$ & Schindler SM, Klegeris A & Special Report & $\begin{array}{l}\text { Subscriber } \\
\text { content }\end{array}$ & [22] \\
\hline 15 & $\begin{array}{l}\text { Changes in brain atrophy indices in patients with } \\
\text { relapsing-remitting multiple sclerosis treated with } \\
\text { natalizumab }\end{array}$ & $\begin{array}{l}\text { Arpín EC, Sobrino TG, Vivero } \\
\text { CD et al. }\end{array}$ & $\begin{array}{l}\text { Short } \\
\text { Communication }\end{array}$ & $\begin{array}{l}\text { Subscriber } \\
\text { content }\end{array}$ & [23] \\
\hline 16 & $\begin{array}{l}\text { Electroconvulsive therapy for depression in } \\
\text { Parkinson's disease: systematic review of evidence and } \\
\text { recommendations }\end{array}$ & $\begin{array}{l}\text { Borisovskaya A, Culbertson } \\
\text { Bryson W, Buchholz J, Samii A, } \\
\text { Borson S }\end{array}$ & $\begin{array}{l}\text { Systematic } \\
\text { Review }\end{array}$ & $\begin{array}{l}\text { Subscriber } \\
\text { content }\end{array}$ & [24] \\
\hline 17 & $\begin{array}{l}\text { Nondopaminergic treatments for Parkinson's } \\
\text { disease: current and future prospects }\end{array}$ & Freitas ME, Fox SH & Review & $\begin{array}{l}\text { Subscriber } \\
\text { content }\end{array}$ & [25] \\
\hline 18 & $\begin{array}{l}\text { The global prevalence of Huntington's disease: a } \\
\text { systematic review and discussion }\end{array}$ & Baig SS, Strong M, Quarrell OWJ & $\begin{array}{l}\text { Systematic } \\
\text { Review }\end{array}$ & $\begin{array}{l}\text { Subscriber } \\
\text { content }\end{array}$ & [26] \\
\hline 19 & $\begin{array}{l}\text { Effects of vigorous walking exercise on core body } \\
\text { temperature and inhibitory control in thermosensitive } \\
\text { persons with multiple sclerosis }\end{array}$ & Sandroff BM, Motl RW, Davis SL & $\begin{array}{l}\text { Short } \\
\text { Communication }\end{array}$ & $\begin{array}{l}\text { Subscriber } \\
\text { content }\end{array}$ & [27] \\
\hline 20 & $\begin{array}{l}\text { The use of facial expressions for pain assessment purposes } \\
\text { in dementia: a narrative review }\end{array}$ & $\begin{array}{l}\text { Oosterman JM, Zwakhalen S, } \\
\text { Sampson EL, Kunz M }\end{array}$ & Review & $\begin{array}{l}\text { Subscriber } \\
\text { content }\end{array}$ & [28] \\
\hline
\end{tabular}

discussing MS, Parkinson's and Alzheimer's disease make up a large proportion of the content. Also included, however, are additional disease areas such as Friedreich's ataxia and Huntington's, alongside more general discussions on dementia. What is interesting to note is the broad spread of article types that make up the top
20 , including the expected reviews and original research, but also commentaries, interviews and editorials. It is our hope at the journal that we can continue to provide our readers with thorough coverage of the neurodegenerative disease landscape, not just with cutting-edge review and research articles, but also the commentary and 
debate that underpins the management of these complex disorders.

\section{Journal indexing}

Awareness of our journal continues to grow, and this year saw the important milestone of the journal being accepted for coverage on Web of Science, via the new Emerging Sources Citation Index [29]. This, alongside our existing coverage in MEDLINE/PubMed, will hopefully ensure our articles are reaching an even wider audience of interested readers.

\section{Community engagement}

As many of you know, Neurodegenerative Disease Management is partnered with knowledge hub Neurology Central [30]. We encourage our readers to sign up to the site, where you can gain access not only to content from our journal free of charge, but also many other partnered journals and website-only original content.

Neurodegenerative Disease Management also offers various services to our authors to increase the speed and reach of their articles - including our accelerated publication and open access options. Interested readers can find out more on our website [31]. We are also pleased to continue working with Kudos in 2017, a service which allows our authors to increase the reach of their articles. For further information, visit their website [32].

Finally, we encourage readers to follow us on Twitter [33] or join our LinkedIn group [34], and share any news or comments with our community.

\section{Conclusion}

2016 was another great year for the journal, and we look forward to working with our authors, editorial board members, reviewers and readers throughout 2017. As always, we welcome any feedback, article proposals or suggestions for future themes and look forward to working with you all over the coming year.

\section{Financial \& competing interests disclosure}

$L$ Dormer is an employee of Future Medicine Ltd. The author has no other relevant affliations or financial involvement with any organization or entity with a financial interest in or financial conflict with the subject matter or materials discussed in the manuscript apart from those disclosed.

No writing assistance was utilized in the production of this manuscript.

\section{References}

1 Miller AE. Teriflunomide in multiple sclerosis: an update. Neurodegener. Dis. Manag. 7(1), 9-29 (2017).

2 Davey DA. Prevention of Alzheimer's disease, cerebrovascular disease and dementia in women: the case for menopause hormone therapy. Neurodegener. Dis. Manag. 7(1), 85-94 (2017).

3 Klaren RE, Hubbard EA, Wetter NC, Sutton BP, Motl RW. Objectively measured sedentary behavior and brain volumetric measurements in multiple sclerosis. Neurodegener. Dis. Manag. 7(1), 31-37 (2017).

4 Hendin B, Huang D, Wray S et al. Subcutaneous peginterferon beta-1a injection-site reaction experience and mitigation: Delphi analysis of the ALLOW study. Neurodegener. Dis. Manag. 7(1), 39-47 (2017).

5 Zesiewicz TA, Chriscoe S, Jimenez T, Upward J, VanMeter S. A fixed-dose, dose-response study of ropinirole prolonged release in early-stage Parkinson's disease. Neurodegener. Dis. Manag. 7(1), 49-59 (2017).
6 Zesiewicz TA, Chriscoe S, Jimenez T, Upward J, Davy M, VanMeter S. A randomized, fixed-dose, dose-response study of ropinirole prolonged release in advanced Parkinson's disease. Neurodegener. Dis. Manag. 7(1), 61-72 (2017).

7 Khalil H, Busse M, Quinn L et al. A pilot study to evaluate the feasibility of a home-based exercise for people with Parkinson's disease in Jordan. Neurodegener. Dis. Manag. 7(1), 73-84 (2017).

8 Kern R. Biogen's portfolio and research efforts in multiple sclerosis - an interview with Dr Ralph Kern. Neurodegener. Dis. Manag. 7(1), 5-7 (2017).

9 Giovannoni G. Gavin Giovannoni on why time matters in multiple sclerosis. Neurodegener. Dis. Manag. 6(2), 77-79 (2016).

10 Güell-Bosch J, Montoliu-Gaya L, EsquerdaCanals G, Villegas S. A $\beta$ immunotherapy for Alzheimer's disease: where are we? Neurodegener. Dis. Manag. 6(3), 179-181 (2016).

11 Lopez G, Monestime G, Sidransky E. Clinical studies of GBA1-associated parkinsonism: progress and challenges. Neurodegener. Dis. Manag. 6(1), 1-4 (2016).
12 Zwerling JL, Cohen JA, Verghese J. Dementia and caregiver stress. Neurodegener. Dis. Manag. 6(2), 69-72 (2016).

13 Gasperi C, Stüve O, Hemmer B. B celldirected therapies in multiple sclerosis. Neurodegener. Dis. Manag. 6(1), 37-47 (2016).

14 Kumar DKV, Eimer WA, Tanzi RE, Moir RD. Alzheimer's disease: the potential therapeutic role of the natural antibiotic amyloid- $\beta$ peptide. Neurodegener. Dis. Manag. 6(5), 345-348 (2016).

15 Aranca TV, Jones TM, Shaw JD et al. Emerging therapies in Friedreich's ataxia. Neurodegener. Dis. Manag. 6(1), 49-65 (2016).

16 García DS, Castrillo JCM, Périz VP et al. Clinical management of patients with advanced Parkinson's disease treated with continuous intestinal infusion of levodopa/ carbidopa. Neurodegener. Dis. Manag. 6(3), 187-202 (2016).

17 Scheperjans F. Can microbiota research change our understanding of neurodegenerative diseases? Neurodegener. Dis. Manag. 6(2), 81-85 (2016).

18 Sivaraman I, Moodley M. Multiple sclerosis in the very young: a case report and review of 
the literature. Neurodegener. Dis. Manag. 6(1), 31-36 (2016).

19 Cucca A, Biagioni MC, Fleisher JE et al. Freezing of gait in Parkinson's disease: from pathophysiology to emerging therapies. Neurodegener. Dis. Manag. 6(5), 431-446 (2016).

20 Dams-O'Connor K, Guetta G, Hahn-Ketter AE, Fedor A. Traumatic brain injury as a risk factor for Alzheimer's disease: current knowledge and future directions. Neurodegener. Dis. Manag. 6(5), 417-429 (2016).

21 Spring JA. Design of evidence-based gardens and garden therapy for neurodisability in Scandinavia: data from 14 sites. Neurodegener. Dis. Manag. 6(2), 87-98 (2016).

22 Schindler SM, Klegeris A. Elucidating the link between the modifiable risk factors of Alzheimer's disease and neuroinflammation. Neurodegener. Dis. Manag. 6(5), 375-384 (2016).

23 Arpín EC, Sobrino TG, Vivero CD et al. Changes in brain atrophy indices in patients with relapsing-remitting multiple sclerosis treated with natalizumab. Neurodegener. Dis. Manag. 6(1), 5-12 (2016).

24 Borisovskaya A, Culbertson Bryson W, Buchholz J, Samii A, Borson S.

Electroconvulsive therapy for depression in Parkinson's disease: systematic review of evidence and recommendations. Neurodegener. Dis. Manag. 6(2), 161-176 (2016).

25 Freitas ME, Fox SH. Nondopaminergic treatments for Parkinson's disease: current and future prospects. Neurodegener. Dis. Manag. 6(3), 249-268 (2016).

26 Baig SS, Strong M, Quarrell OWJ. The global prevalence of Huntington's disease: a systematic review and discussion. Neurodegener. Dis. Manag. 6(4), 331-343 (2016).

27 Sandroff BM, Motl RW, Davis SL. Effects of vigorous walking exercise on core body temperature and inhibitory control in thermosensitive persons with multiple sclerosis. Neurodegener. Dis. Manag. 6(1), 13-21 (2016).
28 Oosterman JM, Zwakhalen S, Sampson EL, Kunz M. The use of facial expressions for pain assessment purposes in dementia: a narrative review. Neurodegener. Dis. Manag. 6(2), 119-131 (2016).

29 Emerging Sources Citation Index. http://ip-science.thomsonreuters.com

30 Neurology Central. www.neurology-central.com

31 Future Science Group Publishing Solutions. www.future-science-group.com/services

32 Kudos. www.growkudos.com/

33 Neurodegenerative Disease Management. Twitter. https://twitter.com/fsgnmt

34 Future Science Group Neurology LinkedIn group. www.linkedin.com/groups/8204606 